\title{
THE ROLE OF THE HUMAN AND STRUCTURAL CAPITAL, INTELLECTUAL CAPITAL AND BUSINESS PERFORMANCE
}

\author{
Rays Muh* \\ Murwaningsari Etty, Lecturer \\ Doctoral Program of Accounting, University of Trisakti, Indonesia \\ *E-mail: $\underline{\text { ddn ramdhani@yahoo.com }}$
}

\begin{abstract}
This study aims to determine the relationship of the implementation of Intellectual Capital to Business Performance on the manufacture company in the province of Banten. Especially purpose of this research is to know the relationship of the Human Capital with Customer Capital, to know the relationship of the Human Capital with Structural Capital, to know the relationship of the Customer Capital with Business Performance, to know the relationship of the Structural Capital with Business Performance. The sample is that used in this research are 46 manufacturing companies on the province of Banten, and the unit of analysis are Finance Manager, Human Resource Development Manager, and Production Manager. Data is that obtained in this research is the primary data with the research instruments such as questionnaires. This research uses Partial Least Square as a means of testing the hypothetical with the Outer and Inner Model. The processing of data was found that the results of the questionnaire as the primary data which represent each variable have level of good reliability that is above 0.5 . Similarly, internal consistency between the independent variables and dependent variables have a both of good validity value is greater than 0.7 . For test hypothetical got results that Human Capital associated with significant positive Customer Capital, which is evidenced by the t-statistics are greater than the t-table that is on the 4.053 $>$ 1.96. Human Capital associated with significant positive Structural Capital, which is evidenced by the t-statistics are greater than the t-table that is on the $7.925>1.96$. Customer Capital has a significant positive relationship to the Business Performance, which is evidenced by the t-statistics are greater than the t-table that is on the $5.664>1.96$. Structural Capital associated not significantly positive to the Business Performance, which is evidenced by the t-statistic is less than the t-table that is on the $1.075<1.96$. Last Intellectual Capital is a significant positive relation with the Business Performance, which is evidenced by the tstatistics are greater than the t-table that is on the $5.436>1.96$.
\end{abstract}

\section{KEY WORDS}

Intellectual capital, human capital, structural capital, customer capital, business performance.

In the era of globalization, technological innovation and intense competition forced companies to change the way they run their business. In order to continue to survive quickly companies change from a business based on labor (labor-based business) towards a knowledge based business (business based on knowledge), with the main characteristics of science. The increase in the value of capitalization shares are quite high and the difference between the book value of capitalized stocks on knowledge based industries the "missing value" in the financial statements by Stewart (1997) later referred to as intellectual capital. Stewart (1997) in Dwi and Arifin (2005) shows the ratio of book value to market value of shares contained in the balance sheet on a knowledge-based company is $1: 7$, while in service companies 1:1. According to Stewart (1997) of such difference because there intangible asset yang not recorded in the balance sheet by the company.

The company's inability to record intangible assets on its balance sheet due to accounting standards that exist today have not been able to capture and report on the investment incurred in obtaining the resources. Non-physical resources that can be captured 
and reported in accordance with accounting standards currently only limited investment in forms of intellectual property.

Conventional accounting systems do not allow the company to capitalize on intangible assets and reported as other assets. So that the financial statements are no longer sufficient for an assessment of the performance and potential value of the company. Thus, accounting is also believed to have not been able to do the recognition and measurement of intellectual capital, because the accounting tends to focus on the assets that are real (hard assets) alone. Even if there are intangible assets are recognized and measured in the financial statements, most of them are based on the historical value (historical cost) instead of its potential to add value (Stewart, 1997) in Dwi and Arifin (2005)

The limitations are a challenge for management accounting and financial accounting. Accounting management requires new tools for managing the investment expertise of employees, to measure the return on investment skills of employees, and information and technology in the long term (IFAC, 1998). While financial accounting requires accounting measurements are not the same between the enterprise with one another to show indicators of intellectual capital, and in need of new measurements that are not based on monetary (Upton, 2001) in Partiwi and Arifin (2005).

Such challenges arise because at this time, the dominant factor in the assessment of a company, especially for high technology companies and professional service is the intellectual capital (Pike, Rylander \& Roos, 2002) .Therefore Therefore, although it is still not possible to give the monetary value of the intellectual capital, but intellectual capital should be considered that the value creation process easy to understand.

Implementation of intellectual capital is something new, not only in Indonesia but also in the global business environment, only a few developed countries that have begun to implement this concept, for example, Australia, the United States and the Scandinavian countries. In addition, in determining the guidelines on measurement Intangible conducted by researchers at the European institutions such as NORDIC, DATI, and MERITUM also not been able to formulate a similar concept to it. But the companies they studied still report as a Voluntary Intellectual Capital Report (Toma's and Ramo'n, 2007).

In Indonesia, according to (Abidin 2000) in Ulum (2008) intellectual capital is still not widely known. In many cases, up to now have companies in Indonesia tend to use conventional business based in the building, so that the resulting product is still poor technological content. Besides, these companies do not pay more attention to human capital, structural capital, and customer capital. Yet all of these are elements of the company's intellectual capital builder

Based on the above, the researchers tried to re-examine the relationship between the application of Intellectual Capital elements consisting of Human Capital, Customer Capital and Structural Capital on Business Performance in the manufacturing companies located in the province of Banten. For this study, entitled "Relationship Analysis Application of Intellectual Capital on Business Performance: Empirical Research on Manufacturing Company in Banten Province".

A problem to be examined in this study can be identified as follows:

1. How is the relationship of the Human Capital Customer Capital in manufacturing companies in the province of Banten;

2. How is the relationship of the Human Capital Structural Capital in manufacturing companies in the province of Banten;

3. How is the relationship to the Business Customer Capital Performance in manufacturing companies in the province of Banten;

4. How Structural Capital relation to the Business Performance in manufacturing companies in the province of Banten;

5. How is the relationship consisting of Intellectual Capital Human Capital, Customer Capital, Structural Capital and Business Performance in manufacturing companies in the province of Banten.

Based on the identification of the problem above, the purpose of this study was to obtain empirical evidence about: 
1. Customer Relationship Human Capital to Capital on manufacturing companies in the province of Banten.

2. Relation to Structural Capital Human Capital in manufacturing companies in the province of Banten.

3. Customer Relationship Capital and Business Performance in manufacturing companies in the province of Banten.

4. Structural Relationship Capital and Business Performance in manufacturing companies in the province of Banten.

5. Relationships Intellectual Capital consists of Human Capital, Customer Capital, Structural Capital and Business Performance in manufacturing companies in the province of Banten.

With the research is expected to provide benefits such as:

Company. Can provide a practical contribution to the company in the management of Intellectual Capital for corporate decision making. Serta into consideration for companies, especially those in Banten province to determine its policy on the application of Intellectual Capital in conjunction with the Business Performance.

Investor. For consideration and performance measurement information in business organizations and also the planting stock was going to do with these companies see the Business Performance

Creditor. For your consideration, and the information in the provision of loan funds will be provided by looking at the application of Intellectual Capital of the company.

Usability Sciences Development:

a. Are expected to contribute in the form of a reference for management accounting, in particular those relating to the measurement of the performance of the business organization, the theory of accounting and financial accounting, primarily related to the theory of the intellectual capital, the discussion of intangible assets preparation of Statement of Financial Accounting Standards (SFAS) with respect to the existence of intellectual capital;

b. Expected to be used as material for further research in the development of knowledge concerning discussion of Intellectual Capital;

c. For authors - to determine the relationship consisting Intellectual Capital Human Capital, Customer Capital, Structural Capital and Business Performance.

\section{LITERATURE REVIEW}

Understanding Intellectual Capital by Sawarjuwono (2003):

"Intellectual capital can be defined as the sum of what is produced by the three main elements of the organization (humancapital, structural capital, customer capital) related to the knowledge and technology to provide more value for the company in the form of competitive advantage of the organization".

Some definitions of intellectual capital are summarized and quoted in Partiwi and Arifin (2005) are as follows:

a. Intellectual capital is exclusive, but once discovered and exploited will give the organization a new resource base to compete and win (Bontis, 1996).

b. Intellectual capital is a term given to a combination of intangible assets from the market, intellectual property, infrastructure and human centers that make a company can function (Brookings, 1996).

c. Intellectual capital is intellectual material (knowledge, information, intellectual property, experience) that can be used to create wealth. It is a collective sense force or set of knowledge that is useful (Stewart, 1997).

d. Intellectual capital is the effective utilization of knowledge (the finished product) as oppose to information (raw materials) (Bontis, 1998).

e. Intellectual capital is considered as an element of the company's market value and also the premium market (Olve, Roy \& Wenter, 1999).

Human capital is the knowledge, skill, and experience brought employees when leaving the company (Starovic \& Marr, 2004) which includes the individual's knowledge of an 
organization (Bontis, Crossan \& Hulland, 2001) generated through competence, attitude and intellectual intelligence (Roos, Roos, Edvinsson and Dragonetti, 1997), in Dwi and Arifin (2005).

In industries based on knowledge, human capital is a major factor for these resources is the dominant cost in the production process of the company, so we can say if all employees in the company then the company will no longer have value. Resources are what will support the creation of structural capital and customer capital which is the core of intellectual capital.

Sawarjuwono (2003) states that "Structural capital is the ability of an organization or company to meet the routine of the company and the structure that supports employee efforts to produce intellectual performance is optimal and overall business performance, for example: systems operations, manufacturing processes, organizational culture, management philosophy and all forms of intellectual property owned by company. An individual can have a high intellectual level, but if the organization has systems and procedures that bad then intellectual capital can achieve optimal performance and potential cannot be fully utilized".

Structural Capital includes the company's ability to reach the market (Petras, 1996) in Widianingrum (2004) or the hardware, software and other supporting companies (Bontis, 2000 ) in other words the infrastructure supporting employee performance. Structural Capital is a link human capital into intellectual capital. That is even though employees have high intellectual, but if not supported by adequate means to apply their innovations, the ability will not generate Intellectual Capital.

According Sawarjuwono (2003), Capital Customer element is a component of intellectual capital that provides real value. Definition of Customer Capital according Sawarjuwono (2003) is: "Customer Capital is a harmonious relationship / association network owned by the company with its partners, both from suppliers and reliable quality, comes from customers loyal and satisfied will the service company concerned, derived from the company's relationship with the government and with local communities. Relational capital may be emerging from different parts of the environment outside companies that can add value for the company".

Customer capital demonstrate the potential of the company since ex-firm intangible (Bontis, 1999), in Dwi and Arifin (2005). Another understanding of Customer Capital is the knowledge of a series of markets, customers, suppliers, relations between government and industry (Bontis, 2000) or a good relationship with outsiders (Petras, 1996) in Widianigrum (2004). So the company had to create goods and services are different and have more value in the eyes of consumers

According to Fuad (2003: 1), in his book defines business as follows: "Business is an activity that cannot be separated from the activities of production, purchase, sale, or exchange of goods and services that involve the person or company for the purpose of generating profits".

According to Hakim (2006: 10), the term of performance or performance often associated with the company's financial condition. Performance is an important thing to be achieved by any company anywhere, because the performance is a reflection of the company's ability to manage and allocate resources.

According to Dwi and Arifin (2005) in his research proves that human capital positively and significantly associated with customer capital. With the tacit knowledge, human capital can create value (value creation), i.e. customer capital for the company. The Company was able to transform tacit knowledge into the knowledge inherent in the company's external relations.

Bontis (1998) and Partiwi (2004) in Dwi and Arifin (2005) also found a significant positive relationship capital and structural human capital. However, the research Bontis et.al (2000) the relationship of human capital and structural capital depending on the industry sector. The relationship between the structural human services industry is positive not significant, while in the non-services industry is a significant positive. Similarly, Dwi and Arifin (2005) which also proves that the human capital positively and significantly associated with structural capital. 
Companies are investing heavily to become a customer focus and a determinant of absolute market will be able to increase or improve its business performance. Consumer is the key to survive the failure of a company. If consumers are loyal to the company, the business performance will be maintained. Partiwi and Arifin (2005) in his research found that the Customer capital and not significantly positively associated with business performance.

Bontis (1998); Bontis et.al (2000) and Partiwi (2004) in Dwi and Arifin (2005) found a significant positive correlation between structural capital and business performance. Thus, the company's efforts to codify knowledge of companies and develop structural capital capable of generating competitive advantages relative yield higher business performance.

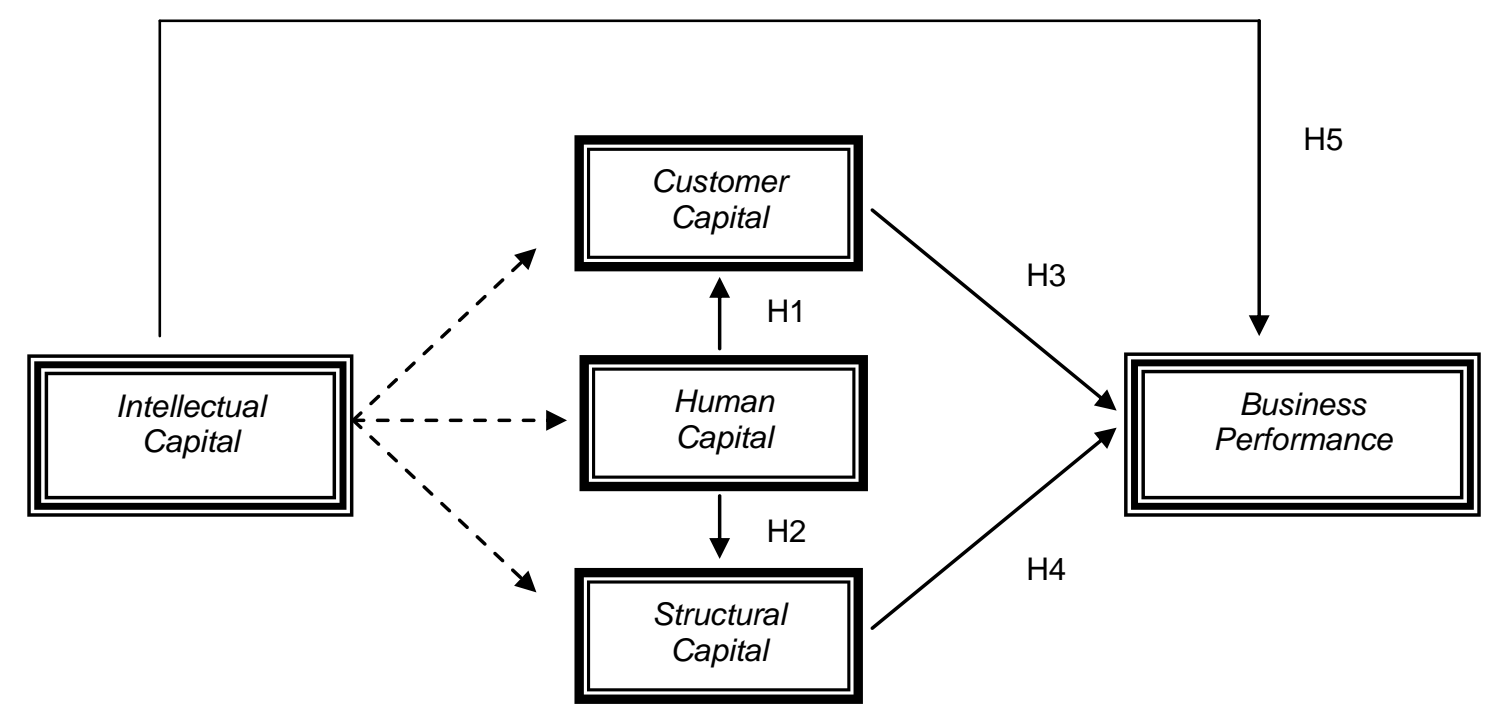

Figure 1 - Relationship Analysis Application of Intellectual Capital to Business Performance (Source: Bontis, 2000)

Based on the above framework, the authors formulate hypotheses as follows:

$\mathrm{H}_{1}$ : Human capital significantly positively associated with Customer Capital;

$\mathrm{H}_{2}$ : Human capital significantly positively associated with Structural Capital;

$\mathrm{H}_{3}$ : Customer capital significantly positively associated with the Business Performance;

$\mathrm{H}_{4}$ : Structural capital significantly positively associated with Business Performance;

$\mathrm{H}_{5}$ : Intellectual Capital consisting of Human Capital, Customer Capital, Structural Capital significantly positively related to Business Performance.

\section{METHODS OF RESEARCH}

The object of this research consists of manufacturing companies located in Banten Province and is registered in the Department of Industry and Trade of Banten Province is located at Jalan Raya Jakarta Km. 4.5 Pakupatan Serang, Banten.

The method used in this research is associative; the research aims to determine the relationship between two or more variables. With this research will be constructed a theory that could serve to explain, predict and control the symptom (Sugiyono, 2007: 11).

The purpose of descriptive research is to describe the situation of widespread problems with the translation of the object being studied and a description of the research that has taken managerial decisions. According Rahayu (2005: 21) analysis is more of a description or explanation by making indicator-table, classifying, analyzing the data based on the results of the questionnaire answers obtained from respondents using data tabulation. This descriptive study used to describe how much the relationship between Intellectual Capital and its elements to the Business Performance in the manufacturing companies located in the province of Banten. 
According to Mohammad Nazir (2003: 123), the indicator is a concept that has become wide value. When creating a conceptualization of indicator variables to be studied should be given boundaries and the following explanation:

1. Independent Variable also called independent variables (variables that affect), which is composed of Intellectual Capital: Human Capital, Customer Capital, and Structural Capital.

2. Dependent Variables also called the dependent variable (the variable that is affected), the Business Performance.

Table 1 - Variable Operationalization

\begin{tabular}{|c|c|c|c|c|}
\hline Variable & Concept of Variables & Indicator & Likert & $\begin{array}{c}\text { Measureme } \\
\text { nt Scale }\end{array}$ \\
\hline $\begin{array}{l}\text { Intellectual } \\
\text { Capital }\end{array}$ & $\begin{array}{l}\text { Intellectual capital can be defined as the } \\
\text { sum of what is produced by the three main } \\
\text { elements of the organization (human } \\
\text { capital, structural capital, and customer } \\
\text { capital) related to knowledge and } \\
\text { technology that can provide more value for } \\
\text { the company in the form of competitive } \\
\text { advantage of the organization. }\end{array}$ & $\begin{array}{l}\text { Human } \\
\text { Capital, } \\
\text { Customer } \\
\text { Capital, } \\
\text { Structural } \\
\text { Capital. }\end{array}$ & $\begin{array}{l}\text { Likert scale was filled to the } \\
\text { extent to which respondents } \\
\text { agree with the seven Likert } \\
\text { scale }(1=\text { very well at all up } \\
\text { to } 7=\text { very well }) \text {. }\end{array}$ & Ordinal \\
\hline Human Capital & $\begin{array}{l}\text { Human Capital is the knowledge, skill, and } \\
\text { experience brought when employees leave } \\
\text { the company that includes the individual's } \\
\text { knowledge of an organization that is on } \\
\text { employees. }\end{array}$ & $\begin{array}{l}\mathrm{H} 1, \mathrm{H} 2, \mathrm{H} 3, \\
\mathrm{H} 4, \mathrm{H} 5 \mathrm{R}, \mathrm{H} 6 \\
\mathrm{H} 7, \mathrm{H} 8\end{array}$ & $\begin{array}{l}\text { Likert scale was filled to the } \\
\text { extent to which respondents } \\
\text { agree with the seven Likert } \\
\text { scale }(1=\text { very well at all up } \\
\text { to } 7=\text { very well). }\end{array}$ & Ordinal \\
\hline $\begin{array}{l}\text { Customer } \\
\text { Capital }\end{array}$ & $\begin{array}{l}\text { Customer Capital is the knowledge of a } \\
\text { series of markets, customers, suppliers, } \\
\text { relations between the government and the } \\
\text { indicator or good relations with outsiders. }\end{array}$ & $\begin{array}{l}\mathrm{C} 1, \mathrm{C} 2, \mathrm{C} 3 \\
\mathrm{C} 4, \mathrm{C} 5, \mathrm{C} 6 \\
\mathrm{C} 7, \mathrm{C} 8\end{array}$ & $\begin{array}{l}\text { Likert scale was filled to the } \\
\text { extent to which respondents } \\
\text { agree with the seven Likert } \\
\text { scale }(1=\text { very well at all up } \\
\text { to } 7=\text { very well). }\end{array}$ & Ordinal \\
\hline $\begin{array}{l}\text { Structural } \\
\text { Capital }\end{array}$ & $\begin{array}{l}\text { Structural Capital includes the company's } \\
\text { ability to reach markets or the hardware, } \\
\text { software and others that support the } \\
\text { company in other words the infrastructure } \\
\text { supporting employee performance. }\end{array}$ & $\begin{array}{l}\text { S1, S2, S3, } \\
\text { S4, S5, S6, } \\
\text { S7, S8. }\end{array}$ & $\begin{array}{l}\text { Likert scale was filled to the } \\
\text { extent to which respondents } \\
\text { agree with the seven Likert } \\
\text { scale }(1=\text { very well at all up } \\
\text { to } 7=\text { very well). }\end{array}$ & Ordinal \\
\hline $\begin{array}{l}\text { Business } \\
\text { Performance }\end{array}$ & $\begin{array}{l}\text { Described in the formal control system } \\
\text { performance measures include the size of } \\
\text { the financial and non-financial. }\end{array}$ & $\begin{array}{l}\text { P1, P2, P3, } \\
\text { P4. }\end{array}$ & $\begin{array}{l}\text { Likert scale was filled to the } \\
\text { extent to which respondents } \\
\text { agree with the seven Likert } \\
\text { scale }(1=\text { very well at all up } \\
\text { to } 7=\text { very well). }\end{array}$ & Ordinal \\
\hline
\end{tabular}

Source: Penulis (2009).
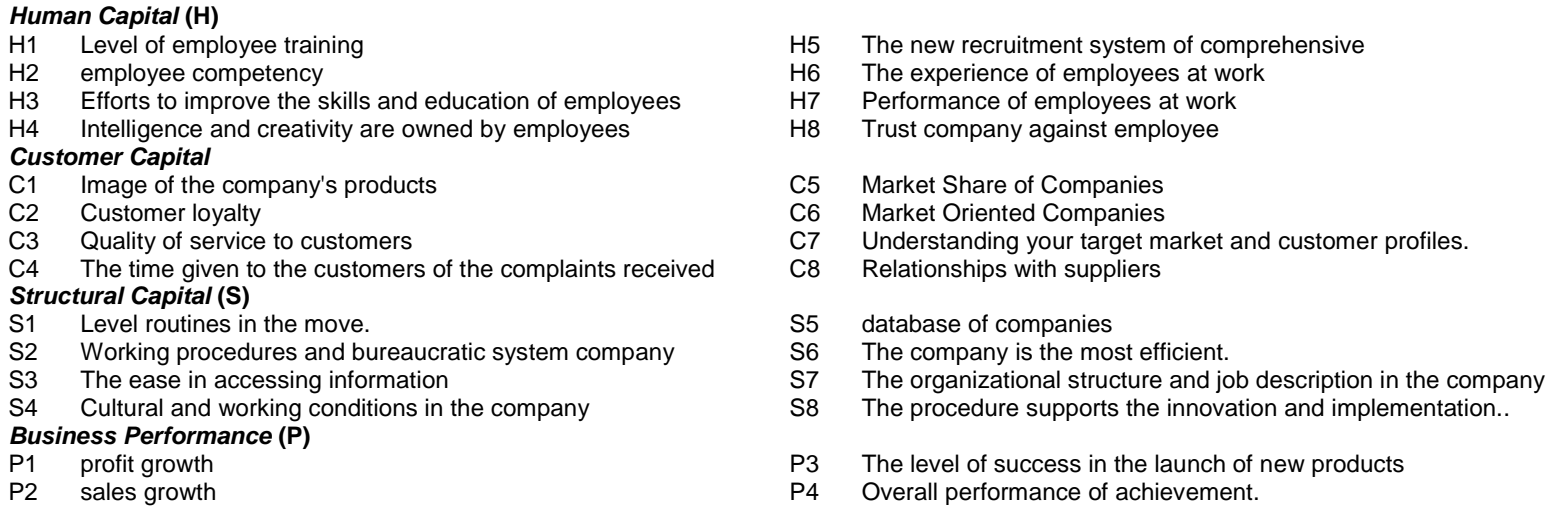

Type of research data is the data subject (self-report data). Source of research data is primary data (primary data) obtained directly from the original source, and through media intermediaries, namely electronic mail. As well as through secondary data is the use of data collected by other parties (library research) related to the research conducted. Sources of data obtained from the Department of Industry and Trade of the Province of Banten and manufacturing companies studied.

This study was conducted to obtain primary data is collected using a questionnaire survey method with data collection by sending a questionnaire via the contact person and 
send e-mail to the respondent. In addition, also for obtaining secondary data, a list of manufacturing companies located in the Department of Industry and Trade of the Province of Banten.

This research is also done by reading and studying reference books and journals to obtain secondary data as the theoretical foundation that is appropriate to the issues raised.

The population of this research is manufacturing companies listed in the Department of Industry and Trade of the Province of Banten, as the sampling framework. Unit research is financial managers, personnel managers and production managers as the company representative.

The sampling technique used in this research is non probability sampling with the sampling pattern is purposive sampling. The population of this research is manufacturing companies listed in the Department of Industry and Trade of the Province of Banten. And the sample in this study is a manufacturing company in Banten province and has met the criteria proposed authors. The sampling criteria as follows:

Table 2 - Criteria Sampling

\begin{tabular}{|c|l|c|}
\hline No. & \multicolumn{1}{|c|}{ Criteria } & Value \\
\hline 1 & Companies listed in the Department of Industry and Trade of the Province of Banten. & 603 \\
\hline 2 & The manufacturing company limited liability and classified into upper and middle companies. & 274 \\
\hline 3 & Manufacturing company which has an investment value of more than Rp. 2.000.000.000, -. & 98 \\
\hline 4 & A manufacturing company that has employees more than 150 people. & 60 \\
\hline \multicolumn{2}{|c|}{ Total Samples } & 60 \\
\hline
\end{tabular}

Source: Penulis (2009).

Analysis of descriptive indicators used in this study is intended to provide an overview of the demographics of the respondents which include gender, age, education, past, position and tenure disclosed to clarify the description of the respondents. Processing descriptive indicator of respondents are using SPSS software version 12.0 (Statistical Product and Service Solution).

Data quality test conducted on the test reliability and validity test software Partial Least Square (PLS) .Uji reliability intended to measure the internal consistency of a questionnaire which is an indicator of the indicator or construct. Measurement reliability tests conducted by test Composite Reliability $\geq 0.70$ (Ghozali, 2006: 43).

The data collection is done with the approach of Structural Equation Model (SEM) using software Partial Least Square (PLS) analysis using PLS.

There are three criteria for assessing outer models: Validity, Diseriminant Validity, and Composite Reliability. Convergent validity of the measurement model with a reflexive indicator assessed based on the correlation between the item score / component score is calculated with the PLS. The size of the individual reflexive said to be high if more than 0.70 correlated with the construct being measured (Ghozali I., 2006):

$$
A V E=\frac{\sum \lambda i^{2}}{\sum \lambda i^{2}+\sum 1 \operatorname{var}\left(\varepsilon_{i}\right)}
$$

Where: $\lambda i$ is the component loading to the indicator and var $(\varepsilon i)=1-\lambda i 2$. Significant AVE value must be greater than the value of 0.50 . formula:

By using the output generated PLS Composite reliability can be calculated by the

$$
\rho c=\frac{\left(\Sigma \lambda_{i}\right)^{2}}{\left(\Sigma \lambda_{i}\right)^{2}+\sum i \operatorname{var}\left(\varepsilon_{i}\right)}
$$

Where: $\lambda \mathrm{i}$ is the component loading into indicators and $\operatorname{var}(\varepsilon i)=1-\lambda i 2$. 
Testing inner structural model or models made to look at the relationship between constructs, significance and R-square value of the model, $\mathrm{f}^{2}$ magnitude can be calculated with the following formula (Ghozali I., 2006):

$$
f^{2}=\frac{R^{2} \text { included }-R^{2} \text { excluded }}{1-R^{2} \text { included }}
$$

Where: $\mathrm{R}^{2}$ included and $\mathrm{R}^{2}$ excluded is $\mathrm{R}$-square of the dependent latent variables as predictors of latent variables used or issued in the structural equation. $F^{2}$ value equal to 0:02, $0: 15$, and 0:35 can be interpreted that the predictor variables have an influence latent small, medium, and large at a structural level.

The sampling technique in this research is using purposive sampling, the sampling technique that is based on specific criteria.

Table 3 - Details Returns Questionnaire

\begin{tabular}{|l|c|c|}
\hline \multicolumn{1}{|c|}{ Information } & Amount & Total \\
\hline Delivery via Email & 16 & - \\
\hline Direct Submission & 44 & - \\
\hline Total Questionnaires were sent & - & 60 \\
\hline Questionnaires were returned by email & 14 & - \\
\hline Questionnaires were taken directly & 32 & - \\
\hline Total Questionnaires were returned & - & 46 \\
\hline Total Questionnaires were used & - & 46 \\
\hline Rate of Return (Response Rate) (46/60 x 100\%) & - & $76.7 \%$ \\
\hline Returns are used & - & $76.7 \%$ \\
\hline
\end{tabular}

Location of Manufacturing

\begin{tabular}{|c|c|c|}
\hline No. & Company location & Amount \\
\hline 1. & Serang & 18 \\
\hline 2. & Cilegon & 11 \\
\hline 3. & Tangerang & 17 \\
\hline \multicolumn{2}{|c|}{ Total Company } & 46 \\
\hline
\end{tabular}

Source: Primary data is processed (2009).

Processing descriptive statistics were used by the author is using SPSS software version 12.0 .

Table 4 - Descriptive Statistics

\begin{tabular}{|c|c|c|c|c|c|}
\hline $\mathrm{n} / \mathrm{n}$ & $N$ & Minimum & Maximum & Mean & Std. Deviation \\
\hline name of Respondent & 46 & 1 & 46 & 23.50 & 13.423 \\
\hline Gender & 46 & 1 & 2 & 1.28 & .455 \\
\hline Respondents age & 46 & 1 & 4 & 2.22 & .513 \\
\hline Last education & 46 & 1 & 3 & 1.93 & .442 \\
\hline Position Respondents & 46 & 1 & 3 & 1.63 & .799 \\
\hline Years of service & 46 & 1 & 4 & 2.04 & .759 \\
\hline Valid N (list wise) & 46 & \multicolumn{4}{l}{}
\end{tabular}

Source: Primary data is processed (2009). 


\section{RESULTS AND DISCUSSION}

Testing the validity of the data in this research is to use the Outer Model PLS software that Convergent validity as seen through the square root value of average variance extracted (AVE) of each construct where the value must be greater than 0.5 .

Table 5 - Average Variance Extracted (AVE)

\begin{tabular}{|c|c|c|c|}
\hline Variable & Average variance extracted (AVE) & $\sqrt{A V E}$ & Information \\
\hline CC & 0.515 & 0.717 & Valid \\
\hline HC & 0.620 & 0.787 & Valid \\
\hline SC & 0.558 & 0.747 & Valid \\
\hline BP & 0.754 & 0.868 & Valid \\
\hline
\end{tabular}

Source: Output Smart PLS (2009).

Table 5 explains the value of AVE and AVE root of the construct of Human Capital, Customer Capital, Structural Capital, Intellectual Capital and Business Performance. The results stated that the root of AVE is greater when compared with the correlation of latent variables, it can be interpreted that the statements in the questionnaire declared invalid.

Similarly, the reliability test, the authors use the Composite software PLS with Reliability. The data is said to be reliable if, composite reliability of more than 0.7

Table 6 - Composite Reliability

\begin{tabular}{|c|c|c|}
\hline Variable & Composite Reliability & Information \\
\hline CC & 0.879 & Reliable \\
\hline HC & 0.907 & Reliable \\
\hline SC & 0.881 & Reliable \\
\hline BP & 0.924 & Reliable \\
\hline
\end{tabular}

Composite Reliability: IC 0.897; BP 0.924. Source: Output Smart PLS (2009).

From Table 6 can be seen that every constructs or latent variables have a value of composite reliability above 0.7 indicating that the internal consistency of the dependent variable (Business Performance) and independent (Intellectual Capital consists of Human Capital, Structural Capital and Customer Capital) have good reliability.

Human Capital has a positive relationship indicated by the value Original sample estimate for 0618 and significant as indicated by the value of t-statistic 4053 was greater than t-table (1.96) against the Customer Capital, Then said first hypothesis is accepted that human capital has a significant positive relationship with the Customer Capital.

Table 7 - Results for inner weights

\begin{tabular}{|c|c|c|c|c|c|}
\hline Variable & original sample estimate & mean of subsamples & Standard deviation & t-statistic & Hipotesis \\
\hline HC $>$ CC & 0.618 & 0.601 & 0.152 & 4.053 & Diterima \\
\hline HC -> SC & 0.779 & 0.775 & 0.098 & 7.925 & Diterima \\
\hline CC -> BP & 0.581 & 0.573 & 0.103 & 5.664 & Diterima \\
\hline SC -> BP & 0.141 & 0.150 & 0.131 & 1.076 & Ditolak \\
\hline
\end{tabular}

R-Square: CC 0.381; SC 0.607; BP 0.460. Source: Output Smart PLS (2009).

Human Capital has a positive relationship indicated by the value Original sample estimate for 0779 and significant as indicated by the value of t-statistics 7925 are greater than t-table (1.96) of the Structural Capital. So we can say the second hypothesis is accepted, the Human Capital has a significant positive relationship with Structural Capital.

Customer Capital has a positive relationship indicated by the value Original sample estimate for 0581 and significant as indicated by the value of 5664 t-statistic greater than ttable (1.96) to the Business Performance. The third hypothesis is accepted, it can be said that Customer Capital has a significant positive relationship with the Business Performance. 
In addition to seeing how much influence among construct one with the other constructs can be seen from the R-square value that comes from goodness-fit test is a test model to a structural model (Inner Model).

Based on the data obtained and subsequently processed are presented in Table 7 Structural Capital have a positive relationship indicated by the value Original sample estimate for 0141 and not significant as indicated by the value of t-statistic 1,076 which is less than t-table (1.96) to the Business Performance. It is said that the fourth hypothesis is rejected Structural Capital had no significant positive relationship with the Business Performance.

Based on the data obtained and then processed authors presented in Table 8, Intellectual Capital as a whole has a positive relationship indicated by the value Original sample estimate for 0597 and significant as indicated by the value of t-statistic 5436, i.e. more than t-table (1.96) to Business Performance. Then said fifth hypothesis is accepted that Intellectual Capital has a significant positive relationship with the Business Performance.

Table 8 - Results for inner weight

\begin{tabular}{|c|c|c|c|c|c|}
\hline Variable & Original sample estimate & Mean of subsamples & Standard deviation & T-Statistic & Hypothesis \\
\hline IC $->$ BP & 0.597 & 0.611 & 0.110 & 5.436 & Accepted \\
\hline
\end{tabular}

R-Square: BP 0.357. Source: Output Smart PLS (2009).

\section{CONCLUSION}

Human Capital significantly positively associated with Customer Capital, as evidenced by the t-statistic is greater than the t-table is 4,053> 1.96 and sample original estimate shows the mean value of 0.618 which correlates positively. This is due to company managers that include financial managers, personnel managers and marketing managers have always sought to maximize the thought of the image products to customers so that customer loyalty is high and the market share and market oriented companies to be increased. This is also supported by the managers of manufacturing companies in the province of Banten always trying to improve the intelligence and competence of its employees through training and education training recruitment system comprehensively, so that got employees who have the intelligence and creativity and work experience satisfactory to the company.

Human Capital significantly positively associated with Structural Capital, as evidenced by the t-statistic is greater than the t-table is 7925> 1.96 and original sample estimate shows the value of 0.779 which means correlates positively. It also indicates that manufacturing firms in Banten Province has a good managerial system. With easy access to the needed information, culture and work environment that supports, a good database management, the implementation of a clear job description, the resulting company can make efficiency and support the creation of innovation and good implementation of its employees. Which is also supported by the employees who are smart and creative and competent in the field of each, so that the work undertaken will get good results, and employees feel safe and comfortable in work.

Customer Capital has a significant positive relationship with the Business Performance, as evidenced by the t-statistic is greater than the t-table is $5664>1.96$ and sample original 0581 estimate shows significant value correlates positively. This indicates the company has been managing capital such good customer understand the target market, the profile and desires of customers, building good relationships with customers and suppliers. Through this, the company can continue to increase its market oriented and its market share as well as the image of the company's products to be good so that the customer loyalty will continue to increase. And this can affect the level of benefit in terms of profit and sales growth that can be seen with the success in launching a new product and performance achievement.

Structural Capital is not significantly positively associated with Business Performance, as evidenced by the t-statistic is less than t-table is $1.075<1.96$, but the original sample estimate still shows positive value of 0141 which means that correlate positively. This is 
because the manufacturing companies in the province of Banten have not been able optimally to improve the company's routines and procedures and bureaucratic system that is not fully done so in general this can weaken Business Performance which is owned by the company.

Intellectual Capital significantly positively associated with Business Performance, as evidenced by the t-statistic is greater than the t-table is $5,436>1.96$ dan original sample estimate shows the value of 0597 which means that correlate positively. This is because in general manufacturing in Banten province has implemented Intellectual Capital on their operations by either consisting of Human Capital, Customer Capital and Structural Capital. With the implementation of intellectual capital then this will affect the level of Business Performance or achievement of better corporate performance. And indirectly will bring benefits in the present and in the future for manufacturing companies in the province of Banten in particular.

Companies in general and manufacturing in particular are expected to further implement the Intellectual Capital consists of Human Capital, Structural Capital and Customer Capital is better. Because it was evident from the preceding discussion, by implementing the Intellectual Capital has an influence on the increase in Business Performance of the company, this is because between Intellectual Capital and Business Performance has a positive relationship.

In further research is expected to expand the scope of the model and used to sample more. So we get a better result and can prove the application of Intellectual Capital in all types of businesses and industries in relation to the Business Performance or the other dependent variables.

\section{REFERENCES}

1. Baridwan, Zaki. "Intermediate Accounting”. Edisi 8. BPFE. Yogyakarta: 2004.

2. Bontis, Nick. et, al. "Intellectual Capital and Business Performance in Malaysian Industries".Journal Of Intellectual Capital. Vol.1 No.1. Pp 85-100. 2000.

3. Cahyono, Dwi. and kawan-kawan. «Pengaruh Moderasi Sistem Pengendalian Manajemen and Inovasi terhadap Kinerja". Simposium Nasional Akuntansi X. Makassar. Pp 1-23. 2007.

4. Dwi Astuti, Partiwi and Arifin Sabeni. "Hubungan Intellectual Capital and Bussines Performance Dengan Diamond Specification: Sebuah Perspektif Akuntansi”. SNA VIII Solo. Pp 694-707. 2005.

5. Fuad, M. and kawan-kawan. «Pengantar Bisnis". PT. Gramedia Pustaka Utama: Jakarta. 2003.

6. Ghozali, Imam. "Structural Equation Modeling, Metode Alternatif dengan Partial Least Square (PLS)".Edisi 2. Badan Penerbit Universitas Diponegoro: Semarang. 2006.

7. Hakim, Rahman.»Perbandingan Kinerja Keuangan Perusahaan Dengan Metode EVA, ROA, and Pengaruhnya terhadap Return Saham pada Perusahaan yang Tergabung dalam Indeks LQ 45 di Bursa Efek Jakarta". Fakultas Ekonomi. Universitas Islam Indonesia:Yogyakarta. 2006.

8. Hong, Pew Tan, David Plowman and Phil Hancock. "Intellectual Capital

9. and Financial Returns of Companies."Journal of Intellectual Capital. Vol 8, No. 1, 76-95. 2007.

10. Ikatan Akuntan Indonesia. "Standar Akuntansi Keuangan Per 1 September 2007". Salemba Empat: Jakarta. 2007.

11. Kuryanto, Benny and M. Syarifudin. "Pengaruh Modal Intelektual terhadap Kinerja Perusahaan". Simposium Nasional XI. Pontianak. Pp 1-22. 2008.

12. Lisvery, Saoria and Irma Y. Ginting. "Aktiva Tidak Bewujud".Jurnal Akuntansi and Keuangan Vol 1, Pp 1-15. 2004.

13. M. Banegil $P$, Tomas's and Ramo'n Sanguino G. "Intangible measurement guidelines: a comparative study in Europe".Journal Intellectual Capital (JIC). Pp 192-204. 2007.

14. Nazir, Moh. "Metode Penelitian". Ghalia Indonesia: Jakarta. 2003. 
15. Rahayu, Sri. "SPSS Versi 12.00 dalam Riset Pemasaran". ALFABETA: Bandung. 2005.

16. Rupidara, Neil Samuel. "Modal Intelektual and Strategi Pengembangan Organisasi and Sumber Daya Manusia”. Paper. Universitas Kristen Satya Wacana. Pp 1-17. 2008.

17. Sawarjuwono, Tjiptohadi and Agustine Prihatin Kadir. "Intellectual Capital: Perlakuan, Pengukuran and Pelaporan (Sebuah Library Research)". Jurnal Akuntansi and Keuangan. Vol 5, No 1, Mei, Pp 35 - 57. 2003.

18. Sugiyono. «Metode Penelitian Bisnis “. Alfabeta: Bandung. 2004.

19. S.R, Soemarso. "Akuntansi Suatu Pengantar". Edisi 5. Salemba Empat: Jakarta. 2005.

20. Ulum, Ihyaul, Imam Ghozali and Anis Chariri. "Intellectual Capital and Kinerja Keuangan Perusahaan; Suatu Analisis dengan Pendekatan Partial Least Square". Simposium Nasional Akuntansi XI. Pontianak. Pp. 1-32. 2008.

21. Widyaningrum, Ambar. "Modal Intelektual". Jurnal Akuntansi and Keuangan Indonesia. Vol 1, pp 16-25. 2004. 